\title{
Extensive reproductive rhythm and early weaning improve body condition and fertility of rabbit does
}

\author{
Alexandre FEUGIER, Laurence FoRTUN-LAMOTHE* \\ Station de Recherches Cunicoles, INRA, BP 52627, 31326 Castanet-Tolosan Cedex, France
}

(Received 23 May 2005 - Accepted 28 April 2006)

\begin{abstract}
This research was aimed at evaluating the respective influence of reproductive rhythm (R), artificial insemination (AI) performed on the 11th or the 25th day after kindling, and age at weaning (W) at 23 or 35 days of lactation, on the evolution of body condition and reproductive performance of rabbit does. Immediately after the initial kindling 12 does were selected for initial slaughter. The 234 primiparous does were assigned at their first parturition to one of four treatments: R11W23, R11W35, R25W23 and R25W35. The does representative of each experimental group were slaughtered at successive stages of the reproduction cycle to evaluate reproductive performance or body condition. When artificial insemination was performed 25 days compared to 11 days after kindling, main dissectible fat weight of the does was lower at insemination $(67 \mathrm{~g}$ vs. $98 \mathrm{~g}$ in R25 and R11 does respectively; $P<0.001$ ). But main dissectible fat weight at second parturition was higher in the R25 than in the R11 group $(+27.3 \% ; P<0.001)$. From the first kindling to AI, the energy balance of does was positive in the R25 group and negative in the R11 group $\left(+847 \mathrm{~kJ} \cdot \mathrm{kg}^{-0.75}\right.$ vs. $-729 \mathrm{~kJ} \cdot \mathrm{kg}^{-0.75}$ in R25 and R11 does respectively; $\left.P<0.015\right)$. Moreover, the R25 does had a higher sexual receptivity at AI (+24 points; $P<0.001)$, and pregnancy rate (+16 points; $P<0.05)$ than the R11 does. Additionally, fœtal viability $(+5.4 \% ; P<0.05)$ was higher in the R25 than R11 groups whereas the number of corpora lutea, number of kits born alive and weight of litter at birth were not affected by reproductive rhythm. An early weaning did not affect the reproductive performance of the does but significantly reduced the main dissectible fat mobilisation $(-35 \%$ vs. $-54 \%$ in W23 and W35 groups respectively; $P<0.001)$ and increased live body (+135 g vs. $-32 \mathrm{~g}, P<0.005)$, empty body ( $+78 \mathrm{~g}$ vs. $-93 \mathrm{~g}, P<0.001)$ and defatted carcass weight gains $(+79 \mathrm{~g}$ vs. $-19 \mathrm{~g}, P<0.001)$ from 1 st to 2 nd parturition. The present results demonstrate that limiting the nutritional solicitation of females by shortening the duration of lactation or the length of superposition between lactation and pregnancy, reduces the body fat mobilisation of primiparous does. The effects of reproductive rhythm and weaning age on corporal condition add together.
\end{abstract}

rabbit does / reproductive rhythm / weaning age / reproductive performance / body condition

Résumé - Un rythme de reproduction extensif associé à un sevrage précoce améliore l'état corporel et la fertilité des lapines. Cette étude a eu pour objectif d'évaluer l'influence respective du rythme de reproduction $(\mathrm{R})$, d'une insémination artificielle $(\mathrm{AI})$ le $11^{\mathrm{e}}$ ou le $25^{\mathrm{e}}$ jour après la mise

* Corresponding author: lamothe@ toulouse.inra.fr 
bas, et de l'âge des lapereaux au sevrage (W) à 23 ou à 35 jours de lactation, sur l'évolution de l'état corporel et les performances de reproduction des lapines. Immédiatement après la première parturition, 12 lapines ont été choisies pour l'abattage initial. Les 234 lapines primipares restantes ont été réparties à leur première parturition dans quatre groupes expérimentaux : AI11W23, AI11W35, AI25W23 et AI25W35. Des femelles représentatives de chacun des groupes expérimentaux ont été sacrifiées tout au long du cycle de reproduction pour évaluer leur performance de reproduction ou leur état corporel. Lorsque l'insémination artificielle a été réalisée 25 jours au lieu de 11 jours après la mise bas, le poids des principaux dépôts adipeux dissécables a été plus faible à l'insémination (67 g vs. $98 \mathrm{~g}$ dans les groupes R25 et R11 respectivement; $P<0,001$ ). Mais le poids de ces principaux dépôts adipeux a été plus élevé $(+27,3 \% ; P<0,001)$ dans le groupe R25 que dans le groupe R11 à la seconde mise bas. De la première mise bas à l'AI, le bilan énergétique des femelles a été positif dans le groupe R25 et négatif dans le groupe R11 $\left(+847 \mathrm{~kJ} \cdot \mathrm{kg}^{-0.75}\right.$ vs. $-729 \mathrm{~kJ} \cdot \mathrm{kg}^{-0.75}$ dans les groupes R25 et R11 respectivement; $P<0.015$ ). De plus, les femelles R25 ont eu une réceptivité sexuelle supérieure (+24 points ; $P<0.001)$, et un taux de gestation accru $(+16$ points ; $P<0.05)$ par rapport aux femelles R11. D'autre part, la viabilité fœtale $(+5,4 \% ; P<0.05)$ a été supérieure dans le groupe R25 comparé au groupe R11 alors que le nombre d'ovules pondus, le nombre de lapereaux nés vivants et le poids de la portée à la naissance n'ont pas été affectés par le rythme de reproduction. Un sevrage plus précoce n'a pas affecté les performances de reproduction des femelles, mais a limité de façon importante la mobilisation des réserves corporelles lipidiques ( $-35 \%$ vs. $-54 \%$ dans les groupes W23 et W35 respectivement ; $P<0,001$ ) et a augmenté le gain de poids vif $(+135 \mathrm{~g}$ vs. $-32 \mathrm{~g}, P<0,005)$, de poids vif vide $(+78 \mathrm{~g}$ vs. $-93 \mathrm{~g}, P<0.001)$ et de poids de carcasse dégraissée $(+79 \mathrm{~g}$ vs. $-19 \mathrm{~g} ; P<0,001)$ de la première à la seconde mise bas. Ces résultats démontrent que limiter la sollicitation nutritionnelle des lapines en réduisant la durée de la lactation ou le temps de superposition de la lactation et de la gestation, réduit la mobilisation des principales réserves adipeuses dissécables des femelles primipares. Les effets du rythme de reproduction et de l'âge au sevrage sur l'état corporel s'additionnent.

lapine / rythme de reproduction / age au sevrage / performance de reproduction / état corporel

\section{INTRODUCTION}

Lactation is the most energetically expensive component of the reproduction cycle in mammals. In rabbit species, energy balance of lactating females is usually negative, and body reserves must be mobilised [19]. Indeed feed intake of rabbit does is not sufficient to meet nutritional requirements for maintenance and milk production [27]. Moreover, rabbit does could be fertilised shortly after parturition, then pregnancy and lactation overlap. In such a situation, the energy deficit increases because the need for milk production and fœtal growth add together [19] and a competition for maternal resources occurs between the suckling litter and foetuses [15]. Previous results demonstrated that an increase of dietary energy content is not sufficient to cancel the energy deficit and avoid intense body mobilisation in primiparous rabbit does [23]. A negative energy balance is detrimental for the reproductive process $[13,17]$ and the length of the reproductive life is shorter in intensively than in extensively reared does [18]. Therefore, it seems interesting to study strategies (other than feeding strategies) which can reduce the energy mobilisation in lactating females and improve their reproductive performance. A new breeding system associating a lengthening of remating interval with an early weaning decreases the duration or cancels the superposition between pregnancy and lactation and could permit to reduce body stores mobilisation [22,29, 30].

This research was aimed at evaluating the respective influence of reproductive rhythm and age at weaning on the evolution of body condition and reproductive performance of rabbit does. 


\section{MATERIALS AND METHODS}

\subsection{Animals and experimental groups}

Two-hundred forty-six pregnant primiparous does were used (INRA line A0067). The experiment lasted until the second kindling (final kindling). The does had their first parturition (day 0) at 154 days of age and at an average live weight of $3924 \pm$ 274 g. Immediately after the initial kindling 12 does were slaughtered to estimate the initial body composition of the remaining does according to the comparative slaughtered technique [19]. The 234 remaining does were assigned to one of four treatments according to their body weight, litter size and litter weight at first parturition. The experimental groups differed on reproductive rhythm: artificial insemination 11 days (R11) or 25 days (R25) after kindling, and weaning age: at 23 (W23) or 35 (W35) days of age. A total of 95 does out of 138 were pregnant and slaughtered at the final kindling in a $2 \times$ 2 factorial arrangement (see Fig. 1). Additional measurements were performed on 96 does slaughtered at artificial insemination or at the 12th day of pregnancy, respecting the chronological differentiation of experimental groups (3 differentiated groups at both intermediary stages, Fig. 1). At artificial insemination, 36 does were slaughtered (12 does in each 3 groups according to their body weight, litter size and litter weight) in order to estimate the body composition at insemination of the remaining does. At the 12th day of pregnancy, 60 pregnant does (20 pregnant does in each 3 groups) were slaughtered to evaluate ovulation rate and fœtal viability.

Artificial insemination was performed in the morning by inseminating $0.5 \mathrm{~mL}$ of heterospermic pools produced by Grimaud Frères S.A. No hormonal synchronisation was performed. Immediately after insemination, ovulation was induced by injecting $0.2 \mathrm{~mL}$ of GnRH $\left(\right.$ Receptal $\left.^{\circledR}\right)$. The litters were equalised at birth to 9 pups by cross fostering or culling. Each doe was caged individually with a controlled light/dark cycle $(16 \mathrm{~h} / 8 \mathrm{~h})$ and had free access to water and diet. During the whole experiment, the females were given a commercial diet formulated to meet the nutritional requirements of reproductive rabbit does in agreement with De Blas and Mateos [7] (DE: $10.57 \mathrm{MJ} \cdot \mathrm{kg}^{-1}, \mathrm{CP}: 166 \mathrm{~g} \cdot \mathrm{kg}^{-1}$, ADF: $193 \mathrm{~g} \cdot \mathrm{kg}^{-1}$, Starch: $139 \mathrm{~g} \cdot \mathrm{kg}^{-1}$ ). Nutritional composition of the diet was measured according to the European Group on Rabbit Nutrition (E.G.R.A.N) [8]. Feed intake of does, litter size and weight of both does and litter were recorded on the days of kindling (1st and 2nd), artificial insemination (AI), weaning and 12 days after AI. Energy balance between initial kindling and artificial insemination was estimated according to Parigi-Bini and Xiccato [21]. Milk production during this period was calculated using the weight gain of the pups [12]. No antibiotics were administered during the trial.

\subsection{Body condition}

The 246 does were slaughtered at successive stages of the reproduction cycle in order to evaluate reproductive performance or body condition. All the does were weighed just before slaughter and killed by cervical dislocation. At each slaughter stage, the does representative of each differentiated group (body weight, litter size and litter weight) were chosen. The comparative slaughter technique was used to estimate the evolution of body composition of the does between initial kindling and AI, and between initial and final kindling.

At slaughter, the defatted carcass, the full digestive tract, skin, kidneys, main dissectible adipose tissues (perirenal and interscapular) and genital tract were weighed. The gut and bladder were 


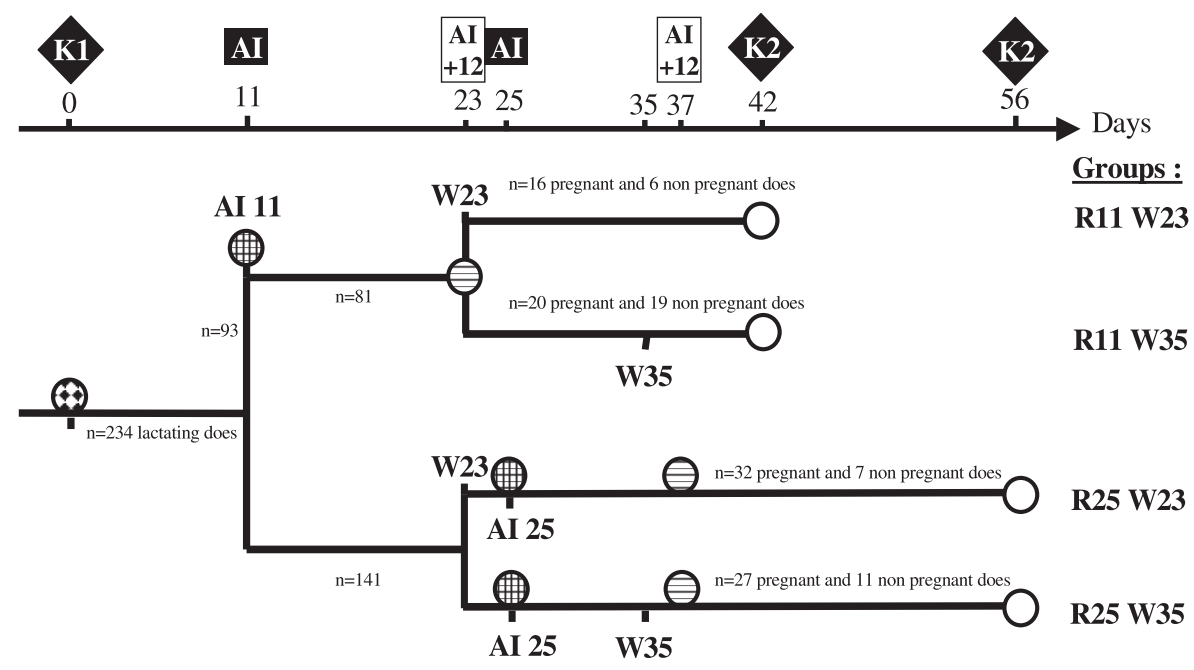

W : Weaning

R : Reproductive rhythm

AI : Artificial insemination

K : Kindling
SLAUGHTERS :

6) Kindling $1: 1$ group ( $\mathrm{n}=12$ does)

曲 $A I: 3$ groups ( $n=12$ does per group)

$\ominus \mathrm{AI}+12$ days : 3 groups ( $\mathrm{n}=\mathbf{2 0}$ pregnant does per group)

Kindling $2: 4$ groups ( $n=95$ pregnant does)

Figure 1. Experimental design.

removed and weighed after emptying. The genital tract was removed and dissected. Empty body weight was defined as live weight minus digestive tract, bladder and uterus contents.

\subsection{Reproductive performance}

Sexual receptivity at insemination was determined using the vulva colour and turgescency according to Rodriguez [24]. Two classes were established: receptive (red or violet and turgescent vulva) and non-receptive females (white or pink and no-turgescent vulva). Does slaughtered at $\mathrm{AI}$ and 12 days after were included in the sexual receptivity estimation.
Fertility was evaluated by abdominal palpation 12 days after AI to determine the pregnancy rate (number of pregnant does $X$ 100 / number of AI). Pregnant does slaughtered on the 12th day of pregnancy were included in the pregnancy rate estimation.

Twelve days after AI, 60 pregnant does were slaughtered to evaluate reproductive performance. The total weight of placentas and foetuses of pregnant does was measured. The number of corpora lutea (CL) was counted to determine the ovulation rate. Foetuses were counted and divided into two classes: (1) live (L), when the fœtus had a visible vascularisation (2) dead (D), when the fœtus had an invisible vascularisation or when the fœetus was resorbed (foetus was represented by a varying amount of placenta tissue and/or fotal 
Table I. Evolution of body composition of the does between 1st and 2nd kindling.



R: Reproductive rhythm.

W: Weaning age.

$\dagger$ : Only pregnant does at second parturition were considered.

$\dagger$ : Perirenal + interscapular fat weights.

membranes). Mortality was defined as follows:

$$
\begin{array}{r}
\text { Embryonic mortality }=(\mathrm{CL}-(\mathrm{L}+\mathrm{D})) \\
\times 100 / \mathrm{CL}
\end{array}
$$

Fœtal mortality $=(\mathrm{R}+\mathrm{D}) \times 100 /(\mathrm{L}+\mathrm{D})$.

It should be noted that embryonic mortality included fertilisation and implantation failures. Litter size and weight were recorded at the second kindling in the remaining females.

\subsection{Data treatment and statistical analysis}

All data were analysed using the Statistical Analysis Systems Institute package
[25]. The weights of animals and organs and feed intake were analysed with analysis of variance (GLM procedure) and receptivity, fertility and mortality were analysed with a chi-square test (procedure CATMOD/SAS). Body composition of the pregnant does between the initial and final kindling (Tab. I) and reproductive performance at weaning and at final kindling (Tab. II) were analysed by a two way analysis of variance (two reproductive rhythm by two weaning age with interaction). No significant interaction between reproductive rhythm and weaning age was recorded either for body composition of the does between initial and final kindling and reproductive performance at weaning and at final parturition. Therefore only the main factors were presented in Tables I and II. Intermediary measurements 
Table II. Reproductive performance of the does at weaning and at final parturition.

\begin{tabular}{|c|c|c|c|c|c|c|c|}
\hline & \multicolumn{2}{|c|}{ Reproductive rhythm } & \multicolumn{2}{|c|}{ Weaning age } & \multirow[b]{2}{*}{ RMSE } & \multicolumn{2}{|c|}{$\operatorname{Pr}>\mathrm{F}$} \\
\hline & R11 & $\mathrm{R} 25$ & W23 & W35 & & $\mathrm{R}$ & $\mathrm{W}$ \\
\hline $\begin{array}{l}\text { No. of does } \\
\text { At weaning }\end{array}$ & 36 & 59 & 48 & 47 & & & \\
\hline No of kits weaned per litter & 8.5 & 8.2 & 8.3 & 8.3 & 1.3 & 0.294 & 0.842 \\
\hline $\begin{array}{l}\text { Weight of litter weaned (g) } \\
\text { At final parturition }\end{array}$ & 5732 & 4931 & 2883 & 7636 & 1043 & 0.151 & $<0.001$ \\
\hline No of kits alive per litter & 13.7 & 13.3 & 13.3 & 13.5 & 2.3 & 0.486 & 0.857 \\
\hline Weight of litter (alive kits) (g) & 728 & 753 & 745 & 742 & 139.3 & 0.410 & 0.903 \\
\hline
\end{tabular}

R: Reproductive rhythm.

W: Weaning age.

$\dagger$ : Only pregnant does at final parturition were considered.

such as body composition and energy balance of the does from kindling 1 to $\mathrm{AI}$ (Tab. III) and quantitative reproductive performance at the 12th day of pregnancy (Tab. IV) were analysed by a one way analysis of variance (3 differentiated groups R11, R25W23, R25W35 representing 2 reproductive rhythms R11 and R25). When the groups differed significantly $(P<0.05)$, differences between means were determined using the Scheffe test.

\section{RESULTS}

\subsection{Body condition and energy balance}

\subsubsection{Energy balance and evolution of body condition between first kindling and AI (Tab. III)}

Live body, empty body and defatted carcass weights at AI, were not affected by reproductive rhythm. On the contrary, the weight of main dissectible fat depots was lower at fertilisation when AI was performed 25 days compared to 11 days after kindling (67 $\mathrm{g}$ vs. $98 \mathrm{~g}$ in R25 and
R11 does respectively; $P<0.001)$. This result was explained by a longer lactation length before $\mathrm{AI}$ in the R25 than in the R11 group. Indeed, the total milk production was $151 \%$ higher (4667 vs. $1858 \mathrm{~g}$ in $\mathrm{R} 25$ and R11 does respectively; $P<0.001$ ) when lactation was on average 13 days longer before AI. However, the energy balance from first kindling to AI was positive in the R25 group and negative in the R11 group (+847 $\mathrm{kJ} \cdot \mathrm{kg}^{-0.75}$ vs. $-729 \mathrm{~kJ} \cdot \mathrm{kg}^{-0.75}$ in R25 and R11 does respectively; $P<$ $0.001)$. This could be related to a higher increase in daily DE intake in the R25 than in the R11 group $(+16.7 \% ; P<0.001)$ compared to the increase of daily milk production $(+10.5 \% ; P<0.015)$. Live body, empty body, defatted carcass weights at AI and energy balance from first kindling to AI were not affected by age at weaning in R25 group.

\subsubsection{Evolution of body condition between first kindling and final kindling (Tab. I)}

At final kindling, live body and defatted carcass weights were not affected by 
Table III. Energy balance and evolution of body composition of the does from first kindling to AI.

\begin{tabular}{|c|c|c|c|c|c|}
\hline \multirow{2}{*}{$\begin{array}{l}\text { Reproductive rhythm } \\
\text { Weaning age }\end{array}$} & \multirow[t]{2}{*}{ R11 } & \multicolumn{2}{|c|}{ R 25 } & \multirow[b]{2}{*}{ RMSE } & \multirow{2}{*}{$\begin{array}{c}\operatorname{Pr}>\mathrm{F} \\
\mathrm{R}\end{array}$} \\
\hline & & W23 & W35 & & \\
\hline No. of does ${ }^{\dagger}$ & 36 & 32 & 27 & & \\
\hline \multicolumn{6}{|l|}{ Initial kindling } \\
\hline Live body (g) & 3933 & 3908 & 3938 & 271 & 0.850 \\
\hline Empty body (g) & 3610 & 3594 & 3614 & 181 & 0.850 \\
\hline Defatted carcass (g) & 2286 & 2278 & 2288 & 91 & 0.850 \\
\hline Fat depots ${ }^{\dagger \dagger}(\mathrm{g})$ & 139 & 137 & 139 & 14 & 0.850 \\
\hline \multicolumn{6}{|l|}{ Artificial insemination } \\
\hline Live body (g) & 4260 & 4067 & 4263 & 282 & 0.856 \\
\hline Empty body (g) & 3823 & 3738 & 3893 & 232 & 0.779 \\
\hline Defatted carcass (g) & 2364 & 2314 & 2406 & 135 & 0.789 \\
\hline Fat depots ${ }^{\dagger \dagger}(\mathrm{g})$ & $98^{\mathrm{a}}$ & $63^{\mathrm{b}}$ & $72^{\mathrm{b}}$ & 16 & $<0.001$ \\
\hline \multicolumn{6}{|c|}{ From initial kindling to artificial insemination } \\
\hline Live body gain (g) & $328^{\mathrm{a}}$ & $160^{\mathrm{b}}$ & $325^{\mathrm{a}}$ & 241 & 0.072 \\
\hline Empty body gain (g) & $213^{\mathrm{a}}$ & $145^{\mathrm{b}}$ & $279^{\mathrm{a}}$ & 184 & 0.867 \\
\hline Defatted carcass gain $(\mathrm{g})$ & $78^{\mathrm{ab}}$ & $36^{\mathrm{b}}$ & $118^{\mathrm{a}}$ & 106 & 0.858 \\
\hline Fat gain $(\mathrm{g})$ & $-41^{\mathrm{a}}$ & $-75^{\mathrm{b}}$ & $-67^{\mathrm{b}}$ & 13 & $<0.001$ \\
\hline Food intake $\left(\mathrm{g} \cdot \mathrm{day}^{-1}\right)$ & $311^{\mathrm{b}}$ & $352^{\mathrm{a}}$ & $369^{\mathrm{a}}$ & 41 & $<0.001$ \\
\hline DE intake $\left(\mathrm{kJ} \cdot \mathrm{day}^{-1} \cdot \mathrm{kg}^{-0.75}\right)$ & $1147^{\mathrm{b}}$ & $1324^{\mathrm{a}}$ & $1356^{\mathrm{a}}$ & 140 & $<0.001$ \\
\hline DE intake $\left(\mathrm{kJ} \cdot \mathrm{kg}^{-0.75}\right)$ & $12620^{\mathrm{b}}$ & $33102^{\mathrm{a}}$ & $33904^{\mathrm{a}}$ & 2794 & $<0.001$ \\
\hline Milk production $\left(\mathrm{g} \cdot \mathrm{day}^{-1}\right)$ & $169^{b}$ & $181^{\mathrm{ab}}$ & $193^{\mathrm{a}}$ & 33 & 0.013 \\
\hline Total milk production $(\mathrm{g})$ & $1858^{\mathrm{b}}$ & $4534^{\mathrm{a}}$ & $4824^{\mathrm{a}}$ & 767 & $<0.001$ \\
\hline Energy balance $\left(\mathrm{kJ} \cdot \mathrm{kg}^{-0.75}\right)$ & $-729^{\mathrm{b}}$ & $+845^{\mathrm{a}}$ & $+849^{\mathrm{a}}$ & 2979 & 0.014 \\
\hline
\end{tabular}

R: Reproductive rhythm.

$\dagger$ : Only pregnant does at second parturition were considered.

$\dagger$ : Perirenal + interscapular fat weights.

a, b, c: Means within each row affected with a different letter are significantly different $(P<0.05)$.

weaning age. However empty body and main dissectible fat depots decreased with increasing weaning age $(-3.7 \% ; P<0.05$, $-27.0 \% ; P<0.001)$. Moreover, all measured parameters at final kindling were influenced by reproductive rhythm. Indeed, live body, empty body, defatted carcass and main dissectible fat weight were higher in R25 than in R11 does $(+3.8 \% ; P<0.05$; $+4.5 \% ; P<0.01 ;+5.0 \% ; P=0.001$; $+27.3 \% ; P<0.001)$.
3.2. Effect of reproductive rhythm and weaning age on reproductive performance

\subsubsection{Effect of reproductive rhythm on reproductive performance at AI and at the 12th day of pregnancy (Tab. IV)}

Sexual receptivity of does $(+24$ points; $P<0.001)$, pregnancy rate $(+16$ points; 
Table IV. Reproductive performance of the does at AI and at the 12th day of pregnancy.

\begin{tabular}{|c|c|c|c|c|c|}
\hline \multirow{2}{*}{$\begin{array}{l}\text { Reproductive rhythm } \\
\text { Weaning age }\end{array}$} & \multirow[t]{2}{*}{ R11 } & \multicolumn{2}{|c|}{ R 25} & \multirow[b]{2}{*}{ RMSE } & \multirow{2}{*}{$\begin{array}{c}\operatorname{Pr}>F \\
R\end{array}$} \\
\hline & & W23 & W35 & & \\
\hline \multicolumn{6}{|c|}{ At artificial insemination } \\
\hline No. of does & 93 & 71 & 70 & & \\
\hline Sexual Receptivity (\%) & $69^{\mathrm{b}}$ & $96^{\mathrm{a}}$ & $90^{\mathrm{a}}$ & & $<0.001$ \\
\hline \multicolumn{6}{|c|}{ At the 12th day of pregnancy } \\
\hline No. of does & 81 & 59 & 58 & & \\
\hline Pregnancy rate & $69^{\mathrm{b}}$ & $88^{\mathrm{a}}$ & $81^{\mathrm{ab}}$ & & 0.012 \\
\hline No. of does & 20 & 20 & 20 & & \\
\hline No. of Corpora Lutea & 16.4 & 16.4 & 17.5 & 1.9 & 0.301 \\
\hline Live fœtus & 13.3 & 13.7 & 14.6 & 2.4 & 0.228 \\
\hline Dead fœtus & $1.9^{\mathrm{a}}$ & $1.3^{\mathrm{ab}}$ & $0.9^{\mathrm{b}}$ & 1.2 & 0.026 \\
\hline Embryonic mortality (\%) & 7.3 & 8.5 & 9.4 & & 0.724 \\
\hline Fœtal mortality (\%) & $12.5^{\mathrm{a}}$ & $8.7^{\mathrm{ab}}$ & $5.5^{\mathrm{b}}$ & & 0.015 \\
\hline Uterus content $(\mathrm{g})$ & 24.2 & 23.5 & 23.1 & 5.7 & 0.633 \\
\hline
\end{tabular}

R: Reproductive rhythm.

a, b, c: Means within each row affected with different letters are significantly different $(P<0.05)$.

$P<0.05)$ and fotal viability $(+5.4 \%$; $P<0.05)$ were higher in primiparous females inseminated 25 days after kindling compared to those inseminated 11 days after kindling. On the contrary, the number of corpora lutea, embryonic mortality and uterus content, observed 12 days after insemination were not affected by reproductive rhythm. When the does were inseminated 25 days after kindling, reproductive performance was not affected by age at weaning.

\subsubsection{Effect of reproductive rhythm and weaning age on reproductive performance at weaning and at final parturition (Tab. II)}

Reproductive rhythm and weaning age did not significantly affect the number of kits born alive per litter and weight of litter at final kindling. Reproductive rhythm did not significantly influence the viability of rabbits of the first litter during lactation. But, the weight of litter at weaning was $61 \%$ lower when weaning occurred at 23 days compared to 35 days of age $(P<0.001)$.

\section{DISCUSSION}

\subsection{Evolution of body stores during the reproductive cycle}

In the present study, the objective of early weaning was to reduce the lactation length and the nutritional needs linked to milk synthesis and thus to limit the body mobilisation of the does. Our results show that weaning age strongly influenced the evolution of body condition during the reproductive cycle. As expected, the weight of main dissectible fat depots at the second kindling was higher in early than in later weaned females. This was in agreement with the results of Xiccato et al. [28] who reported a reduction of fat loss $(-76 \mathrm{~g}$, $-129 \mathrm{~g}$ and $-170 \mathrm{~g}$ in does weaned at 21 , 26 and 32 days respectively) and energy 
deficit $(-8 \%,-14 \%$ and $-19 \%$ in does weaned at 21, 26 and 32 days respectively) between initial and final kindling in early weaned females. Reproductive rhythm is also implicated in the evolution of the female's body condition during the reproductive cycle. Indeed, main dissectible fat depots and protein body stores of the does are higher at final kindling when artificial insemination is performed later after previous parturition. In the same way, Parigi-Bini et al. [20] showed a higher energy deficit at second kindling in does remated 12 days after the first kindling compared to females remated 28 days after the first kindling. Anyway, in this study the primiparous does were unable to restore at the final kindling their initial body stores, whatever the remating interval (weaning at 28 days). The results of Xiccato et al. [29] showed a higher mobilisation of body fat between first and second kindling in the most intensive reproductive rhythm (does inseminated 2 days compared to 11 and 26 days after kindling). On the contrary, these authors observed no significant difference in the evolution of body composition between initial and final kindling in females fertilised at 11 or 26 days of lactation.

Our results suggested that the effect of both weaning age and reproductive rhythm on the evolution of body composition add together. The beneficial effect of a short lactation on mobilisation of adipose tissue at final kindling is higher when females are fertilised later after a previous kindling. The lower mobilisation of adipose tissue at final kindling was observed in does inseminated two days after an early weaning. A combination of reproductive rhythm and weaning age determines the length of the dry period during which the females could recover the body reserves they mobilised during lactation. The length of the dry period is strongly related to body condition at subsequent kindling.

\subsection{Influence of reproductive rhythm and weaning age on reproductive performance}

Our data showed a close relation between the vulva appearance and fertility, in agreement with previous results [26]. Sexual receptivity was higher when the remating interval increased. This agreed with the results of Castellini et al. [4]. Additionally, pregnancy rate increased when does were mated later after kindling. This confirmed the progressive recovery of reproductive ability of rabbits does during lactation $[4,5,16,18]$. In the present work, the pregnancy rate of females was not affected by age at weaning. Besides, pregnancy rate of females inseminated 25 days after parturition was not significantly different in lactating and weaned does. However, Xiccato et al. [31] observed the best reproductive performance in post weaning mated does. These authors suggested that it could be explained both by favourable body energy condition and hormonal status. In the same way, Castellini et al. [4] showed that an alternating reproductive rhythm (insemination 1 day after parturition alternated with 1 day after weaning which occurred at 26 days of age) improves the fertility rate compared to a fixed remating interval (11 days post partum).

The number of corpora lutea was not affected by remating interval. But foetal mortality decreased when remating interval increased. This was in agreement with the results of Parigi-Bini et al. [20] and confirmed the detrimental effect of concurrent pregnancy and lactation on fotal viability [11]. However, the effects of remating interval on fœtal mortality were too small to significantly affect the litter size at birth. Cervera et al. [5] observed a higher prolificity when the remating interval increased. Previous results [11] showed that in simultaneously pregnant and lactating does, a competition for nutrient uptake occurs between the uterus 
and mammary gland that is detrimental to fœetal growth. Indeed weight at birth $(52.6$ vs. $51.8 \mathrm{~g})$ and lipid $(-33 \%)$, protein $(-2.3 \%)$ and energy contents $(-4.8 \%)$ of new-born litters are lower when mothers are both pregnant and lactating [11]. In the present work, the duration of the superposition between pregnancy and lactation, modified by reproductive rhythm and lactation length, did not affect uterine content nor litter weight at birth. Therefore, in all experimental groups, the dry period might be long enough to allow a compensatory growth. None of the reproductive performance parameters registered at final kindling were affected by the length of lactation. This was in agreement with the results of Xiccato et al. [30].

\subsection{Relationship between nutritional status and fertility}

The daily feed intake and daily milk production between kindling and AI were higher when AI occurred 25 compared to 11 days after parturition. This result confirmed the positive relation between milk production and feed intake during lactation $[9,14]$. Indeed, milk synthesis represents a high nutritional demand and the female's feed intake progressively increases during lactation to satisfy these greater needs. Energy balance from first kindling to AI was negative when does were inseminated 11 days after kindling and positive when does were inseminated the 25th day after kindling. This could be explained by an increase of daily DE intake higher than the increase of daily milk production during this period. Such a situation could explain the better pregnancy rate observed in females fertilised later in lactation. This result was in accordance with a positive effect of increasing energy intake before mating on the conception rate of multiparous rabbit does [10]. The weight of fat depots at insemination was lower in R25 compared to R11 does. Therefore, main dissectible fat depots at the moment of insemination were not directly linked with fertility.

Chilliard et al. [6] showed that several mechanisms are implicated to avoid excessive fat mobilisation and/or to recover the body fatness homeostatic set point. Indeed, in the underfeeding condition, homeostasis and homeorhesis control determines dynamic reproductive events and the survival of the females [3]. Bauman and Currie [1] emphasised that if an environmental challenge is of sufficient magnitude (such as underfeeding condition), homeostatic controls for survival can overwhelm homeorhetic mechanisms operating in support of a physiological function.

The energy deficit associated with milk production partly explained the negative influence of lactation on reproductive performance of rabbit females [11] as observed in other farm animals [2]. Hormone levels (prolactin, oxytocin) associated with lactation could also be involved in the negative effect of lactation on pregnancy rate. But the effects of energy deficit and hormone levels depending on lactation stage were confused in the present experiment.

\section{CONCLUSION}

Nature has accorded a high priority to the function of lactation allowing it to proceed at the expense of the function of pregnancy when they overlap. The energy deficit generated by milk production negatively affects the pregnancy rate of females inseminated during lactation. The present results demonstrate that limiting the nutritional solicitation of females by shortening the duration of lactation or the length of superposition between lactation and pregnancy, reduces the body fat mobilisation of primiparous rabbit does. The effects of reproductive rhythm and weaning age on corporal condition add together. A reduction 
of reproductive rhythm increases the pregnancy rate of females partly due to a positive energy balance before insemination. On the contrary, the weaning age did not affect reproductive performance of the does. Such a result needs to be confirmed in multiparous does for which feed intake and thus nutrient supply are higher. Management practice using remating interval and weaning age also need to be further studied on the lifespan of females.

\section{ACKNOWLEDGEMENTS}

The authors wish to acknowledge the personal of the Élevage Alternatif et Santé des Monogastriques (INRA Le Magneraud, France) especially E. Lamothe, for the expert technical assistance. This study was supported by INRA and Région Poitou Charentes.

\section{REFERENCES}

[1] Bauman D.E., Currie W.B., Partitioning of nutrients during pregnancy and lactation: A review of mechanisms involving homeostasis and homeorhesis, J. Dairy Sci. 63 (1980) 1514-1525.

[2] Blanc F., Martin Graeme B., Bocquier F., Modelling reproduction in farm animals. A review, Reprod. Fert. Develop. 13 (2001) 337-353.

[3] Blanc F., Bocquier F., Debus N., Agabriel J., D’hour P., Chillard Y., La pérennité et la durabilité des élevages de ruminants dépendent des capacités adaptatives des femelles, INRA Prod. Anim. 17 (2004) 287-302.

[4] Castellini C., Dal Bosco A., Mugnai C., Comparison of different reproduction protocols for rabbit does: effect of litter size and mating interval, Livest. Prod. Sci. 83 (2003) 131-139.

[5] Cervera C., Fernandez-Carmona J., Viudes de Castro P., Blas E., Effect of remating interval and diet on the performance of female rabbits and their litter, Anim. Prod. 56 (1993) 399-405.

[6] Chilliard Y., Ferlay A., Faulconnier Y., Bonnet M., Rouel J., Bocquier F., Adipose tissue metabolism and its role in adaptations to undernutrition in ruminants, Proc. Nutr. Soc. 59 (2000) 127-134.
[7] De Blas J.C., Mateos G.G., Feed formulation, in: De Blas J.C., Wiseman J. (Eds.), The Nutrition of the rabbit, CABI publishing, CAB Int., Wallingford, Oxon, UK, 1998, pp. 241-253.

[8] European Group on Rabbit Nutrition (EGRAN), Technical note: Attempts to harmonise chemical analyses of feeds and faeces, for rabbit feed evaluation, World Rabbit Sci. 9 (2001) 57-64.

[9] Fortun-Lamothe L., Energy balance and reproductive performance in rabbit does, Anim. Reprod. Sci. 93 (2005) 1-15.

[10] Fortun-Lamothe L., Effects of pre-mating energy intake on reproductive performance of rabbit does, Anim. Sci. 66 (1998) 263269.

[11] Fortun-Lamothe L., Prunier A., Effects of lactation, energetic deficit and remating interval on reproductive performance of primiparous rabbit does, Anim. Reprod. Sci. 55 (1999) 289-298.

[12] Fortun-Lamothe L., Sabater F., Estimation de la production laitière des lapines à partir de la croissance des lapereaux, $10^{\mathrm{e}}$ Journ. Rech. Cunicole Fr., Paris, France, 19-20 novembre 2003, pp. 69-72.

[13] I'anson H., Foster D.L., Foxcroft G.R., Booth P.J., Nutrition and reproduction, Rev. Reprod. Biol. 8 (1992) 239-311.

[14] Lebas F., Influence de la taille de la portée et de la production laitière sur la quantité d'aliment ingérée par la lapine allaitante, Reprod. Nutr. Dev. 27 (1987) 207-208.

[15] Martínez-Gómez M., Juárez M., Distel H., Hudson R., Overlapping litters and reproductive performance in the domestic rabbit, Physiol. Behav. 82 (2004) 629-636.

[16] Mendez J., De Blas J.C., Fraga M.J., The effects of diet and remating interval after parturition on the reproductive performance of the commercial doe rabbits, J. Anim. Sci. 62 (1986) 1624-1634.

[17] Monget P., Martin G.B., Nutrition et reproduction des animaux d'élevage, Cah. Nut. Diet. 32 (1997) 166-172.

[18] Parigi-Bini R., Xiccato G., Cinetto M., Influenza dell' intervallo partoaccoppiamento sulle prestazioni riproduttive delle coniglie fattrici, Coniglicoltura 7 (1989) 51-57.

[19] Parigi-Bini R., Xiccato G., Cinetto M., Dalle-Zotte A., Energy and protein utilization and partition in rabbit does concurrently pregnant and lactating, Anim. Prod. 55 (1992) 153-162. 
[20] Parigi-Bini R., Xiccato G., Dalle-Zotte A., Carazzolo A., Castellini C., Stradaioli G., Effect of remating interval and diet on the performance and energy balance of rabbit does, Proc 6th World Rabbit Congress, Toulouse, France, 1996, pp. 253-258.

[21] Parigi-Bini R., Xiccato G., Energy metabolism and requirements, in: De Blas J.C., Wiseman J. (Eds.), The Nutrition of the rabbit, $\mathrm{CABI}$ publishing, $\mathrm{CAB}$ Int., Wallingford, Oxon, UK, 1998, pp. 103-131.

[22] Pascual J.J., Early weaning of young rabbits: a review, World Rabbit Sci. 9 (2001) 165170.

[23] Pascual J.J., Cervera C., Blas E., FernandezCarmona J., High-energy diets for reproductive rabbit does: effect of energy source, Nutr. Abstr. Rev. 73 (2003) 27R-39R.

[24] Rodriguez J.M., Ubilla E., Effect of sexual receptivity on ovulation response in rabbit does induced with GnRH, Proc 4th World Rabbit Congress, Budapest, Hungary, 1988, pp. 504-508.

[25] Statistical Analysis System, SAS User's Guide, version 8, SAS Institute Inc., Cary, NC, 1999.

[26] Theau-Clément M., Roustan A., A study on relationships between receptivity and lactation in the doe, and their influence on reproductive performance, Proc. 5th World Rabbit Congress, Corvallis, USA, 1992, pp. 55-62.

[27] Xiccato G., Nutrition of lactating does, Proc. 6th World Rabbit Congress, Toulouse, 1996, pp. 29-47.

[28] Xiccato G., Trocino A., Queaque P.I., Sartori A., Effect of weaning age and parity order on reproductive performance and body balance of rabbit does, Proc. 2nd meeting of workgroups 3 and 4, COST Action 848, Godollo, Hungary, 2001, pp. 54-55.

[29] Xiccato G., Trocino A., Sartori A., Queaque P.I., Effect of reproductive rhythm and litter weaning age on the performance and body energy balance of rabbit does, Proc. 8th World Rabbit Congress, Puebla, Mexico, 2004, pp. 1029-1034.

[30] Xiccato G., Trocino A., Sartori A., Queaque P.I., Effect of parity order and litter weaning age on the performance and body energy balance of rabbit does, Livest. Prod. Sci. 85 (2004) 239-251.

[31] Xiccato G., Trocino A., Boiti C., Brecchia G., Reproductive rhythm and litter weaning age as they affect rabbbit doe performance and body energy balance, Anim. Sci. 81 (2005) 289-296.

To access this journal online: www.edpsciences.org 